\section{Seeing the invisible: brand authenticity and the cultural production of queer imagination}

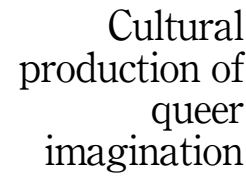

275

Jonatan Södergren

School of Business, Stockholm University, Stockholm, Sweden, and

Niklas Vallström

Marketing, Canterbury Christ Church University, Royal Tunbridge Wells, UK
Received 13 December 2020 Revised 16 March 2021 Accepted 17 March 2021

\begin{abstract}
Purpose - The twofold aim of this theory-building article is to raise questions about the ability of queer cinema to transform market culture and ideologies around gender and sexuality. First, the authors examine how the very capitalization of queer signifiers may compromise the dominant order from within. Second, the authors address how brands possibly can draw on these signifiers to project authenticity.

Design/methodology/approach - Through visual methods of film criticism and the semiotic analysis of three films (Moonlight, Call Me By Your Name and Portrait of a Lady on Fire), the authors outline some profound narrative tensions addressed by movie makers seeking to give an authentic voice to queer lives.

Findings - Brands can tap into these narrative attempts at "seeing the invisible" to signify authenticity. False sublation, i.e. the "catch-22" of commodifying the queer imaginaries one seeks to represent, follows from a Marcusean analysis.

Practical implications - In more practical terms, "seeing the invisible" is proposed as a cultural branding technique. To be felicitous, one has to circumvent three narrative traditions: pathologization, rationalization and trivialization.

Originality/value - In contrast to Marcuse's pessimist view emphasizing its affirmative aspects, the authors conclude that such commodification in the long term may have transformative effects on the dominant ideology. This is because even if something is banished to the realm of imagination, e.g. through aesthetic semblance, it can still be enacted in real life.
\end{abstract}

Keywords Authenticity, Commodification, False sublation, Queer imagination

Paper type Research paper

The authentic oeuvre is not and cannot be a prop of oppression (Marcuse, 1969).

\section{Introduction}

Remember the comic relief when Robin Williams dressed up as a female housekeeper to be able to interact with his estranged children in Mrs. Doubtfire (1993)? Or, Dustin Hoffman as a bad-tempered actor whose reputation for being difficult forces him to adopt a new identity as a woman to land on a job in Tootsie (1982)? Even the gender-bending performance when Marlene Dietrich - the breakout star of the silent era - was first introduced to an American audience in Morocco (1930) typifies the widespread commodification of queer culture in the embellished halls of Tinseltown (Horak, 2016). Commodification has been defined as the process of treating some object - "a person, place, thing, event, idea or whatever" (Holbrook, 1995, p. 641) - as a commodity to be shaped, packaged, distributed and marketed.

(C) Jonatan Södergren and Niklas Vallström. Published by Emerald Publishing Limited. This article is published under the Creative Commons Attribution (CC BY 4.0) licence. Anyone may reproduce, distribute, translate and create derivative works of this article (for both commercial and non-commercial purposes), subject to full attribution to the original publication and authors. The full terms of this license may be seen at http://creativecommons.org/licences/by/4.0/legalcode
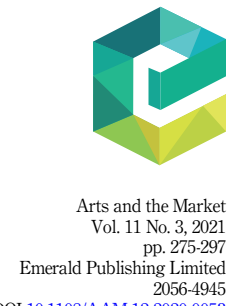

DOI 10.1108/A 2056-4945 
AAM

11,3

276

Not long ago, it was difficult to imagine queer lives being depicted with respectability in mainstream cinema. As recently as in 2003, it was considered shocking when Britney Spears and Madonna kissed on stage while performing at the MTV VMAs. However, the commercial and critical success of movies such as Moonlight (2016), Call Me By Your Name (2017) and Portrait of a Lady on Fire (2019) indicate a cultural disruption from which queer imagination is proposed as an ideological structure that increasingly seems to inform how the audience derives authenticity from the screen. In light of such cultural change, the diversity of queer narratives is now increasingly present in the culture industries (Halberstam, 2005; also Jones, 2009). Even the online role-playing video game World of Warcraft has included its first transgender character (Hafer, 2020). As the plurality of femininities and masculinities remains in constant motion, cultural production opens up opportunities for extensions of nonhegemonic sexual identities into the realm of aesthetic consumer culture (see, e.g. Coffin et al., 2019; Ginder and Byun, 2015; Gluckman and Reed, 1997; Gurrieri and Cherrier, 2013; Seregina, 2019; Skinner, 2018; Peñaloza, 1996; Thompson and Üstüner, 2015).

The concept of authenticity has received much scrutinization in cultural sociology (e.g. Fine, 2003; Grazian, 2005; Peterson, 2005), exceeding to the marketing and brand management literature (Beverland and Farrelly, 2010; see Södergren, 2021, for a review; Thompson et al., 2006). Marketing gurus Gilmore and Pine (2007) suggest that brand authenticity has now overtaken quality as a prevailing purchase criterion. For the purpose of this paper, authenticity is understood as the outcome of a dynamic framing process wherein certain agencies attain legitimacy (Kates, 2004). Scholars have called for more research on the social, political and cultural processes through which consumer experiences are authenticated (e.g. Södergren, 2019; Wilson, 2011). The way consumers interpret authenticity in cinematic artwork has recently been elaborated in relation to race, specifically the black community in America (DeBerry-Spence and Izberk-Bilgin, 2019). Feminist perspectives also have a long tradition within marketing and consumer research scholarship (see Hearn and Hein, 2015). For example, Bristor and Fischer (1993) demonstrate that:

links between gender imagery and marketer/consumer relationships can be traced to some of the earliest marketing texts [...] which explicitly cast the consumer as female and pit the marketing manager (referred to with masculine pronouns) against the consumer, advising him on how to get her to buy (p. 528).

However, there is a pressing need to understand how queer discourses, circulated through popular culture, are appropriated to endow consumer experiences with a celebratory flair. Opportunities arise for brands to tap into these discourses to signify authenticity. Indeed, brands are increasingly expected to take a stand on sociopolitical issues (see Vredenburg et al., 2020). The aim of this study is to elucidate how the commodification of queer aesthetics can have transformative effects on market culture and its dominant ideologies. As such, we extend previous literature on market co-optation, which tends to emphasize how counterculture reinforces consumer capitalism (e.g. Heath and Potter, 2005). Toward this aim, the paper is organized as follows. We first review the relevant literature, specifying the theoretical gap that we address. This is followed by the theoretical framework based on the two paraphernalias of queer imagination and false sublation. Then, we present the visual methods employed to analyze the three films. This is followed by the findings in relation to arts marketing and cultural branding. Finally, the contributions and some implications for further research are indicated.

\section{Theoretical background}

Authenticity originally derives from the Greek words autos ("self") and hentes ("doer" "being"), thus signifying that someone is acting on their own authority, not being influenced 
by external pressures (Spiggle et al., 2012). Nowadays, it is often used to signify that something is the genuine or "real thing" (Beverland and Farrelly, 2010). Södergren (2021) identifies three streams of research in the literature on brand authenticity: (1) characteristics that distinguish the "real thing" from the fake, (2) the legitimizing function of authenticity and (3) emotional and moral aspects of authentication. The first stream seeks to denote attributes that are endowed with authenticity (e.g. genuineness, integrity, sincerity). This stream tends to be epistemologically oriented and has recently seen a "quantification" where items are incorporated into the continuous crystallization of brand authenticity scales (e.g. Morhart et al., 2015; Napoli et al., 2014; Schallehn et al., 2014). While such work is important, it may be unable to account for unexpected results, such as ambiguity (Brown et al., 2013) and consumer inclination to suspend disbelief (Stern, 1994). It also tends to associate authenticity with positive attributes, whereby the construct is often mistaken for enchantment (Hartmann and Ostberg, 2013).

A second stream shows how the "authentic oeuvre" can be used as a prop to attain market legitimacy. From this more sociological perspective, by tapping into queer discourses in popular culture, brands can come to signify authenticity. Hence, authenticity is regarded as an alibi that can be used by brands to downplay their commercial intentions (Beverland, 2005) and legitimize their market activities (Thompson et al., 2013). However, scant research in this stream has conceptualized the ideological formation of authenticity magmatically as a compromise between contending discourses of power, i.e. as a process in constant motion where fluidity merely takes on the appearance of solidity through social stratification.

The third stream is closely linked to what Wang (1999) calls existential or postmodern authenticity, i.e. how consumers possibly derive authenticity from an experience even if the setting can be said to be staged in nominal terms. This liminal perspective is prevalent in the tourism literature where tourists at exotic locations may feel as if they are in touch with their true inner selves (Arnould and Price, 2000). From this perspective, authenticity is experiential rather than intrinsic to the object. As such, authentic brands can serve as symbolic resources for self-construction (Holt, 2004).

The purpose of this paper is to extend the second research stream by studying how the commodification of subversive practices is not only affirmative, but can also have transformative effects on market culture and its dominant ideologies. Consider, for example, Lady Gaga who became a figurehead for hermaphrodites all over the world when it was rumored that she had a penis (Lasic, 2020). There is a (mis)conception that authenticity is supposed to be uncompromising. Previous literature has highlighted the rebel and the social outlaw as epitomes of authenticity (e.g. Botterill, 2007; Fine, 2003; Holt and Thompson, 2004). While this is in line with countercultural mythologization in general, our argument is that subversive practices that allow for compromise may have an even greater potential to transform the dominant order from within. As Fisher (2021) points out, "we have to imagine a transformation out of where we are now" (pp. 194-195, italics in original). For that purpose, we propose a theoretical framework based on (1) queer imagination and (2) false sublation. The first is a novel concept rooted in queer theory and the literature of James Baldwin; the latter is an art-historian concept that is useful for studying market co-optation.

\section{James Baldwin's queer imagination}

In our conceptualization of queer imagination, we draw on James Baldwin, a canonical figure in both African-American and gay literary studies whose literary legacy is implicitly characterized by intersectionality. As Brown (2015a) and many other marketing consultants have contended, literary criticism can help enhance branding understanding. Baldwin's oeuvre, ranging from groundbreaking essays (e.g. The Fire Next Time (1963), Notes of a Native Son (1964)) exploring racial and social issues to fictive, often semi-autobiographical
Cultural
production of
queer
imagination

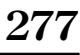



Head (1979)), is, therefore, often acknowledged as a touchstone in the field of queer theory. Working beyond prescribed identity categories, Baldwin's writings have been applauded for "seeing the invisible" such as illegitimate desires in the cultural imaginary, often between men and often between races. Indeed, Brim (2014) argues that Baldwin's most unfailing characteristic as a writer is "his investment in drawing 'impossible' yet undeniable desires into the realm of literary representation" (p. 8). In other words, he renders unseen realities intelligible, which is taken to be central to queer imaginative work.

What is more, Brim (2014) traces the imaginative dynamic that emerges out of a vexed relationship between queerness and normative practices as represented in Baldwin's vast body of work. More specifically, he notes that the distinction between the queer and the normative needs to be re-imagined beyond a liberation/constraint paradigm (cf. Firat and Venkatesh, 1995). It would, thus, seem that queer narratives not only offer emancipatory futures but are also under pressure of normative inscription in the present. As such, they do not operate in distinct opposition to cultural hegemony but rather as a form of unpredictable, often idiosyncratic subversion. Brim (2014) shares a compelling metaphor, "in our field of vision, the queer sky and the normative sea share a broad and blurred horizon" (p. 3). Much of the most influential queer theoretical work, including the literary legacy of James Baldwin, has taken place within this line of convergence. Queer imagination (i.e. those unintelligible realities that are inscribed in the social imaginary, yet excluded from cultural hegemony) is thus proposed to help articulate an alternative power dynamic that can overcome the aforementioned conundrum by elucidating the mutually symbiotic relationship between queer narratives and embodied consumer experience.

Central to this framework is the notion of queer - as opposed to reproductive temporality, as elaborated by queer theorist Jack Halberstam. In short, Halberstam (2005) argues, "queer subcultures produce alternative temporalities by allowing their participants to believe that their futures can be imagined according to logics that lie outside those paradigmatic markers of life experience - namely, birth, marriage, reproduction, and death" (p. 2). By articulating and elaborating the concept of queer time, which is inherent in the queer imagination concept, Halberstam (2005) suggests new ways of understanding non-normative behavior that has clear but not essential relations to gay and lesbian subjects. In this sense, queer refers broadly to non-normative logics and organizations of community, sexual identity, embodiment and activity in both space and time.

Queer lives have attracted substantial attention from filmmakers dedicated to forcing the queer subject to make sense. While one would not wish to assign queerness to the inauspicious category of nonsense, Halberstam (2005) reminds us, "we should be wary of overly rational narratives of lives filled with contradiction and tension" (p. 54). In total, Halberstam (2005) identifies three sets of motivations behind various representations of queer lives in cinema: (1) the project of stabilization, (2) the project of rationalization and (3) the project of trivialization. In the first project, the destabilizing effects of the queer narrative are defused by establishing the queer narrative as strange, uncharacteristic, even pathological. Consider, for example, Dressed to Kill (1980) and Psycho (1960), which both depict men crossdressing as women to commit murders. Secondly, within a rationalizing project, the filmmaker finds reasonable explanations for behavior that may seem dangerous and outrageous at first glance. The queer narrative then placates mainstream viewers by returning the temporarily queer subject to the conforming and seemingly inevitable matrix of hetero-domesticity. A significant part of our analysis is dedicated to describing how the films included in our dataset circumvent issues of rationalization. Finally, a third narrative told about queer subjects to contain the threat they represent to gender stability is a trivializing one in which the queer life is dismissed as non-representative and inconsequential. 
This narrative is present in the films that were mentioned in the introduction (i.e. Morocco, Mrs. Doubtfire, Tootsie).

\section{A false sublation?}

As noted by Gerstner (2019), "hetero-normative and culture-industry ideologies work hand in hand since their fusion profits by the wish to sustain a progressive future" (p. 701). Hence, we must outline how the ideological structure of queer imagination fits among other discourses of power such as heteronormative and culture-industry ideologies in cinematic artwork (Preece, 2014), which raises issues of false sublation. In short, false sublation could be understood as protests that end up protecting the status quo (Bürger, 1984). In Hegelian philosophy, an epoch can only be comprehended when it is approaching its end (i.e. its sublation). By applying the concept of sublation to art history, Bürger (1984) demonstrates that the social function of art only becomes possible to analyze when its institution reaches its end. For example, with the radical separation of aestheticist or modernist art from society, which enabled the avant-gardist attack on art as an institution (Brown, 2015b). Gerstner (2019) suggests that issues of false sublation also could be at stake in queer cinema, as it is subsumed by the very heteronormative and culture-industrial ideologies that profit from its countercultural authenticity (Heath and Potter, 2005).

Following Herbert Marcuse (1968, 1972,1977), who is often associated with the Frankfurt School of critical thought, art has a twofold social function. On the one hand, artwork given over to the ideological reproduction of society offers the "beautiful appearance" or "semblance" of a better world. On the other hand, autonomous artwork - containing the hope for change - functions by creating hope through its very existence for the realization of social ideas in the future. As such, Marcuse shows that art has a simultaneously aesthetic and social effect. On that note, some scholars have suggested that we now live in a brand culture in which the measures for autonomous artwork also apply to (authentic) brands (e.g. Beverland et al., 2020).

Furthermore, Marcuse (1977) maintains that even the most critical art inevitably exhibits a dialectic unity of affirmation and negation. It would, thus, seem that queer cinema holds a precarious position in society due to the institutional juxtaposition of art from social praxis. Queer cinema could be said to protest against the alienation in society by insisting on certain ideals in the future (also Muñoz, 2009). However, because it is detached from society, the same films run the risk of degenerating into a compensation from what society lacks, where they ultimately serve to affirm social conditions. As such, queer cinema follows the many expressions of post-avant-gardist art that could be said to simultaneously protest and protect the status quo. In other words, from a Marcusean perspective, queer cinema serves a contradictory function. On the one hand, it "sees the invisible" akin to Baldwin's literature; on the other hand, such desires are detached from reality through the symbolic function of art to point to further meaning through aesthetic semblance, thus stabilizing the very social conditions against which it protests.

Drawing upon Marcuse, it would seem that normative political ideology exiles queer values to the realm of imagination, thus preventing their potential realization. Consequently, queer imagination is affirmative because it banishes these values to a sphere that is distinct from daily life. The term affirmative characterizes the contradictory function of a culture that retains "resemblance of what could be," but is simultaneously a "justification of the established form of existence" (Marcuse, 1968, p. 98). Because cinema is detached from daily life, this experience remains without tangible effect as it cannot be integrated into that life. However, as Bürger (1984) reminds us, the lack of tangible effects is not the same as functionlessness but characterizes a specific function, namely, the neutralization of critique. In other words, it relieves the existing society of the pressure of those forces that make for change (Marcuse, 1968), for example through repressive tolerance (e.g. "what is proclaimed

\section{Cultural production of queer imagination}

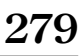


AAM 11,3

280

and practiced as tolerance today, is in many of its most effective manifestations serving the cause of oppression") (Marcuse, 1969, p. 95). While initially used to denote the horrors we tolerate to keep the economy going (e.g. unemployment, social inequality, environmental degradation), we understand repressive tolerance as intertwined with the social functioning of aesthetics. Herein lies a paradox - art no longer distinct from the praxis of life, but wholly absorbed in it, loses the capability to criticize social conditions.

However, we derive that increasingly tolerant and non-polemical representations of queer temporalities and non-hysterical homoeroticism in mainstream cinema ultimately pushes the boundaries from intelligibility to respectability, and consequently diversifies the ideological formation around gender and sexuality by reducing social issues of intolerance, homophobia and other forms of inequity in everyday life. Hence, a less pessimistic view on the radical potential to integrate art into life praxis is offered. In the context of Sámi tourism [1], for example, De Bernardi (2019) demonstrates that authenticity is a compromise between various discourses of power, ranging from tourists and indigenous Sámi people to institutions such as UNESCO that define the authenticity of the heritage experience. The view of authenticity as a compromise could be useful in the performative setting of mainstream queer cinema where discourses of power also include culture-industries and the heteronormative discourse of popular culture. It may also serve as a useful addition to the legitimizing function of authenticity research stream (Södergren, 2021).

In total, applying the above reasoning to the context of queer cinema, the following conceptual framework of the ability of queer cinema to transform market ideologies around gender and sexuality is proposed.

We define performances in queer cinema as characters' actions, verbal statements and other messages in queer cinema that may concern social norms and cultural ideologies. False sublation (i.e. the "catch-22" of commodifying the queer imaginaries one seeks to represent) follows from a Marcusean analysis. However, within the inevitable dialectic of integration and affirmation lies the paradox that false sublation might be necessary for queer imaginaries to have transformative effects on commodity aesthetics, thus integrating queer imagination into social praxis. For example, as Vygotsky (2004) reminds us, imagination ultimately becomes reality because we can act out our imaginations in the real world. In other words, the ideas that are conjured up in our minds become just as real as our memories and influence our attitudes and behaviors, as manifested in the queer imaginaries disseminated in popular culture. What previous research on commodification (e.g. of countercultural authenticity by the fashion system) misses is precisely the last step of our model, i.e. between a false sublation and its longitudinal capacity to transform commodity aesthetics, thus compromising normative political ideology.

\section{Method}

The aim of this study is to raise questions about the ability of cinematic artwork to transform market culture and ideologies around gender and sexuality by elucidating the narrative attempts at "seeing the invisible" in recent queer cinema. Brown and Patterson (2001) argue that we can no longer ignore the various forces of cultural production processes that have come into play in the unfolding of marketing and consumption practices. Schroeder (2005) suggests that awareness of the interconnection between the arts, culture and marketing can provide a better understanding of branding as a strategic signifying practice. Similarly, Bradshaw (2010) notes:

if scholars understand marketing texts to be cultural objects that emerge from creative practice, then it is appropriate to turn to methods such as those developed in literary theory and art history to develop understandings (p. 9). 
De Lauretis (1991) first introduced the term queer theory with the intention to articulate the terms in which queer identity may be understood and imagined as resistance to cultural homogenization. In a similar vein, Derrida (2016) reminds us that écriture extends itself beyond the limits of the pen. In this sense, it would seem that "cinema studies pairs well with queer theory's core commitment to inter-disciplinarity" (Gerstner, 2019, p. 701). Film theory has also made its way into marketing research on gender representations and other forms of resistance to cultural homogenization (e.g. Holbrook and Grayson, 1986; Schroeder and Zwick, 2004). On the one hand, Keating and McLoughlin (2005) note that film remains one of the most widely available and accessible media through which queer representation can be viewed. On the other hand, Kates (2000) argues that gay and independent cinema typically targets a so-called "art-house" audience, and is thus only screened on a very limited number of distribution channels, whereas mainstream cinema has an infinitely wider reach. Therefore, we narrow our data collection to recent cinema that could be said to "queer the halls" of popular culture. In this study, we consider as queer cinema those films that describe and address issues relevant to gays and lesbians (also Benshoff and Griffin, 2004).

For the purpose of our analysis, the focus was on three recent films that have garnered a monolith impact on the global mediascape (Table 1). After watching a total of 71 films in the genre of queer cinema (see Appendix for an extended overview), these films were selected on basis of their representation of different intersections of identity, ranging from class (Call Me By Your Name) and gender (Portrait of a Lady on Fire) to race (Moonlight). Taken together, these films raise questions about consequences when queer cinema is subsumed into the realm of popular culture.

Visual methods have a long tradition in interpretive consumer research (e.g. Hirschman, 1987; Hudson and Ozanne, 1988; Mick, 1986). Hirschman (1988) demonstrates how consumers on a daily basis acquire messages about products from a plethora of media vehicles, including motion pictures. These messages may, for example, concern social norms and cultural ideologies. For the purpose of this study, we were guided by the semiological approach suggested by Holbrook and Grayson (1986). More precisely, notes were taken by both authors independently on a scene-by-scene basis to record the on-screen events (e.g. characters' actions, verbal statements, milieux) with the aim of denoting major (i.e. "large themes and broad characterizations associated with the film's central story" Holbrook and Grayson, 1986, p. 375) and minor (i.e. "more fine-grained nuances of plot and character" Holbrook and Grayson, 1986) encoding habits. The authors met regularly as the analysis progressed, to discuss and make analysis-related decisions and to discuss emerging interpretations. Emphasis was on the narrative projects of those characters whose experience subverted

\begin{tabular}{|c|c|c|c|}
\hline Title & $\begin{array}{l}\text { Initial } \\
\text { release }\end{array}$ & Director & Plot \\
\hline Moonlight & 2016 & Barry Jenkins & $\begin{array}{l}\text { A young African-American man grapples with his } \\
\text { identity and sexuality while experiencing the everyday } \\
\text { struggles of childhood, adolescence and burgeoning } \\
\text { adulthood }\end{array}$ \\
\hline $\begin{array}{l}\text { Call Me By Your } \\
\text { Name }\end{array}$ & 2017 & $\begin{array}{l}\text { Luca } \\
\text { Guadagnino }\end{array}$ & $\begin{array}{l}\text { Set in } 1983 \text { Italy where a romance blossoms between Elio, } \\
\text { a } 17 \text {-year-old student, and Oliver, a slightly older research } \\
\text { assistant hired by his father }\end{array}$ \\
\hline $\begin{array}{l}\text { Portrait of a Lady } \\
\text { on Fire }\end{array}$ & 2019 & $\begin{array}{l}\text { Céline } \\
\text { Sciamma }\end{array}$ & $\begin{array}{l}\text { Takes place on an isolated island in Brittany at the end of } \\
\text { the 18th century where a female painter falls in love with } \\
\text { the betrothed woman whose wedding portrait she is } \\
\text { obliged to paint }\end{array}$ \\
\hline
\end{tabular}

Cultural production of queer imagination

281
Table 1. List of films 
heteronormativity. Coinciding with the data collection, reviews by film critics as well as 11,3 interviews with directors and several actors were also used as secondary data.

\section{Findings and analysis}

In each of the three films, part of the claim for authenticity (or "woke" legitimacy) lies in its compromising effects on the heteronormative discourse of popular culture (e.g. to shape ideologies around gender and sexuality). They are, in a sense, all coming-of-age dramas wherein the sexually ambiguous protagonist tackles their homoerotic desires and sexual awakenings, albeit with completely different pretexts.

\section{Call Me By Your Name}

Based on the eponymous novel by André Aciman, Call Me By Your Name (2017) is the final instalment in Italian film director Luca Guadagnino's thematically themed Desire Trilogy. Its cumulative worldwide gross is estimated to US $\$ 41.9 \mathrm{~m}$ against a production budget of US $\$ 3.4 \mathrm{~m}$ (Box Office Mojo, 2018). In one review, The Guardian's film critic Peter Bradshaw (2017) describes it as "[a]n erotic pastoral that culminates in a quite amazing speech by Michael Stuhlbarg, playing the boy's father. It's a compelling dramatic gesture of wisdom, understanding and what I can only call moral goodness."

Already in the opening credits, we are introduced to Hellenic sculptures seemingly signifying antiquity ideals of homoeroticism. In the first scene, we encounter Elio with his girlfriend Marzia indicating that he is about to grow up into a normative performance of masculinity by entering the repro time of heteronormativity (Halberstam, 2005). From the window, they watch as Oliver first arrives. Elio comments, "He seems confident," and his skepticism toward Oliver implies that he has not yet come to terms with his own burgeoning sexuality. Elio's sexual confusion continues to build up throughout the first $30 \mathrm{~min}$ of the film. In one scene, Oliver touches Elio during a volleyball game and wants to give him a massage while Elio does not know how to react. Oliver picks up on his confusion and saves the situation by the heterosexual alibi of getting one of the girls to touch him too.

In another scene, Oliver is dancing with a girl to the song Love My Way by the British artrockers The Psychedelic Furs. The lyrics "Love my way/It's a new road" implies what lies ahead: the beginning of a journey between Elio and Oliver. Elio, who is enviously watching Oliver on the dancefloor, eventually joins in, but as he cannot yet dance with Oliver due to the social stigma, he settles for dancing with a girl. Unable to escape the hegemonic expectations of repro time, Elio ends up night swimming with Marzia in romantic twilight. By the table next day, Elio says, "We almost had sex yesterday, Marzia and me," whereupon his father replies, "Why did not you?" Elio responds, "I do not know" and Oliver teasingly adds, "It's better to have tried and failed. ..." Elio's parents seem to understand that he is conflicted and implicitly address the issue when his mother loudly recites a fairytale about a princess in love: "Is it better to speak or to die? It's better to speak, she said." The conversation instils a sense that the parents are aware of Elio's bisexual awakening. Furthermore, this conversation is a key moment in the film, as it seems to affect Elio a great deal. From this moment, he is ready to speak his love. Culminating in a discussion about a different historical event altogether, Elio cryptically reveals his love for Oliver who picks up on it and responds, "We cannot talk about those kinds of things," indicating that he too is coming to terms with his homoerotic desire. The film then builds up to an intimate situation between the pair in a private realm, where the interaction, revolving the notion of being Jewish in discretion, somehow seems metaphorical for their hitherto concealed sexual desires. Oliver is taken aback by this situation that has stirred up the equilibrium and starts to deny Elio. Coming back home late one night, he just shuts the door and goes to sleep, upon which Elio repeatedly calls him a traitor. 
Struggling with keeping up the façade of heteronormative masculinity, Elio is instead drawn to having sexual intercourse with Marzia. The scene is a lot more explicit than when Elio and Oliver eventually have sexual intercourse. Censorship is emphasized in regards to gay intimacy, whereas most of Marzia's female body is exposed. Are we not ready for an explicit homosexual sex scene in mainstream cinema? Or, is the focus on the gentle, such as how Elio and Oliver stroke and caress each other, meant to signify that their love is more genuine? Furthermore, from an intersectionality perspective, Call Me By Your Name could be criticized for fetishizing the bisexual curiosity between two white intellectuals while silencing the working class. In the movie, Elio comes from a highly cultivated and wealthy household; therefore, he can afford spending each season idly waiting for the next, just drifting about on his bike reading paperbacks. His intellectual capital is further reinforced by his ability to transpose classical music by ear. In a similar vein, at one point early in the movie, Oliver corrects Elio's father on the etymological origins of the word apricot, indicating that he too is blessed by the credentials of some bohemian intelligentsia. Seldom occupied with work, he has time to read Heidegger, Heraclitus and Stendahl for pleasure. Further, whereas Elio and Oliver's passing love affair is endowed with an aura of authenticity, the only other homosexual couple in the movie - condescendingly referred to as Sonny and Cher - are depicted as stereotypically sassy. When Elio offers some homophobic remarks about the elderly gay couple, his father asks, "Is it because they're gay or because they're ridiculous?" Second, another intersectional critique could be raised in relation to the film's systemic silencing of the working class. At no point during the movie is the maid, Mafalda, given a voice. Hence, the film ultimately misses the point of seeing the invisible. However, it does have one thing in common with queer imagination as elaborated in the literary works of Baldwin's gay novels; the queer episodes are barred to the foreign of a European Other. In the final scene, when Oliver has returned back home to the "real" world of America, he calls the Perlman family who are in the midst of celebrating Hanukkah. Over the phone, he tells Elio that he has gotten engaged to a woman he has been going out with for years, echoing the narrative in Baldwin's Giovanni's Room (1956). By doing so, the film seemingly falls within a rationalizing project, returning at least one of the temporarily queer subject to the conforming and seemingly inevitable matrix of hetero-domesticity. However, returning to Figure 1, we argue that it is because of this false sublation that the film also has compromising effects on normative political ideology.

\section{Moonlight}

Moonlight is an American film written and directed by Barry Jenkins (2016). Depicting three chapters in Chiron's troubled life - first as a boy (Alex Hibbert) taken under the wing of a local drug-dealer; then as a teen (Ashton Sanders) who falls in love with his best friend and finally, as a man (Trevante Rhodes) who must resolve his inner identity with his toughened-up exterior - it became the first film with an all-black cast, as well as the first lesbian, gay, bisexual, transgender and queer (LGBTQ) + related film, to win the Oscar for Best Picture. Its cumulative worldwide gross is estimated to US\$65.3m against a budget of US\$4m (Box Office Mojo, 2017).

Set in the Miami neighborhood of Liberty City, the film opens with the sound of water and modulation of Boris Gardiner's (1973) hit Every Nigger Is a Star. A scrawny kid nicknamed "Little" is chased into a derelict house by his bullies. He is rescued by Juan, a drug-dealer who ends up taking a sort of parental interest in the boy. Neglected by his drug-addicted mother, Chiron struggles to carve his own path in life throughout the film. For instance, at one point, he rushes away while playing with the other boys. His friend Kevin, who seems to show genuine affection for him, comes along and sympathetically asks why he lets other kids pick on him. In a tender yet powerful act, they end up wrestling breathlessly in a scene that not 


\section{1,3}

\section{4}

Figure 1.

Authenticity as a false sublation and its compromising effects on normative political ideology

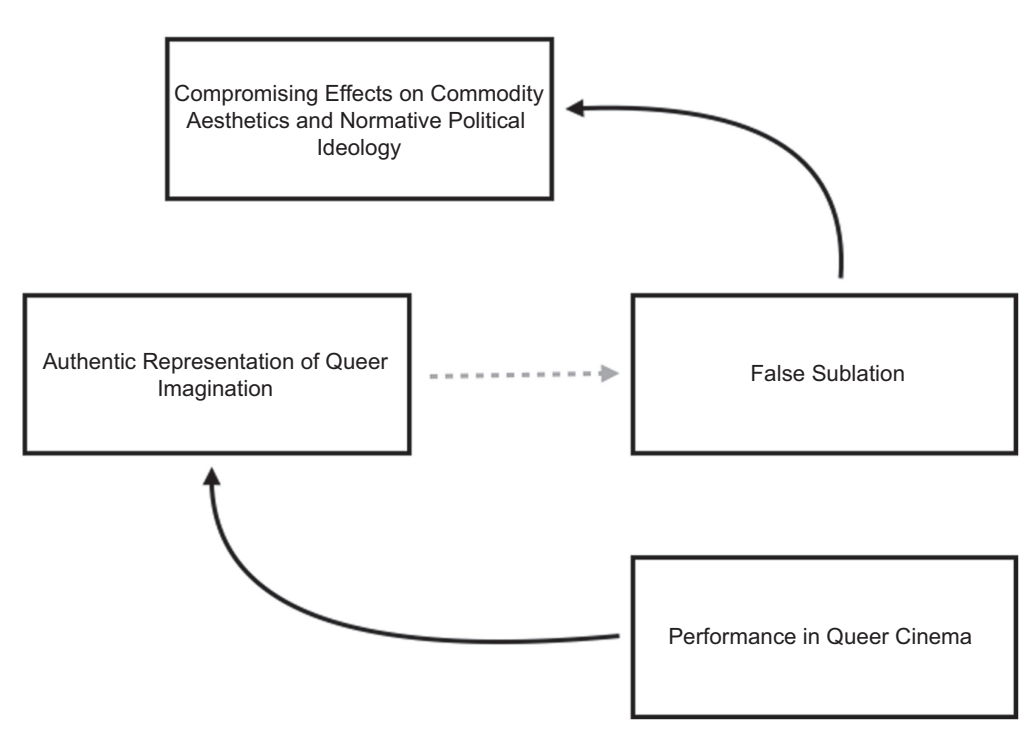

only signifies a pre-adolescent performance of masculinity, but also establishes the impending homosexual awakening. Another emotional sequence is when Juan, who has now taken on something akin to a fatherly role, teaches Chiron how to swim. It would seem that water becomes a key metaphor for Chiron's repressed desires. Another scene related to Chiron's sexual awakening is when he walks into his peers in the school bathroom when they are comparing the sizes of their penises. This seems to relate to the notion of curiosity that is part of growing up as a male; a queer act that is sanitized because the subjects have not yet entered repro time. However, while telling Juan that he hates his mother, maybe because he feels haunted - both by his sexual orientation and his relationship to his psychologically abusive mother - he asks, "What's a faggot?" by which Juan responds, "A faggot is a word you use to make gay people feel bad." Chiron then asks, "Am I a faggot?" Juan says, "No. . . no. You can be gay but you do not have to let nobody call you a faggot." Finally, he asks, "How do I know?"

As a teenager in the film's second chapter, Chiron (Ashton Sanders) wakes up from his daydreaming when a classmate, Terrel, makes fun of him for being effeminate. When hiding from Terrel and the other bullies after class, Kevin approaches Chiron, they still seem to be friendly with each other. Kevin boasts that he got detention for having sex with a girl in the school hallway. Chiron's reserved response indicates that it might be more than just a friendship. Indeed, while sharing a secretive smoke by the water, Chiron admits to Kevin that he wants to do a lot of things that do not make sense, further reiterating his sexual confusion. They end up kissing, and Kevin gives him a handjob; with striking poignancy, we are reminded of the sound of water at the point of sexual climax. Chiron says, "I'm sorry," whereupon Kevin responds, "What have you got to be sorry for?" In the car, Kevin asks if Chiron has done anything like that before. Chiron shakes his head. The following day, Terrel and the other bullies make Kevin punch Chiron in a game of "knockdown, stay down." The increasingly violent performance of masculinity literally becomes an embodiment of Butler's (2006) heterosexual matrix, where Chiron needs to be punished for his homosexuality. More specifically, Chiron has to toughen up to survive, as manifested in the act of retaliation when 
he grabs a chair from the classroom and smashes it against the back of Terrel's head with all his power. Destabilized, he is then taken by the police as Kevin helplessly watches on.

As an adult in the film's final act, Chiron (Trevante Rhodes) has now straightened up and mastered his performance of masculinity to perfection. Yet, something tragic and traumatic seems to loom over the façade; it would seem that the specter of Juan, the only fatherly figure in his life, lingers in Chiron's hardened exterior as he now, too, has become a drug-dealer. Two relationships seem to affirm his post-adolescent identity. First, the tearful reconciliation with his mother, who is now in a drug treatment center. Second, Kevin, who one day calls him out of the blue. Chiron drives all night to visit Kevin at the restaurant in Miami where he is now working. They have not seen each other in a decade. Over a bottle of wine, Kevin shows a picture of his son with his ex-girlfriend and says that he feels fulfilled in his role as a father. Chiron looks at him with a slightly melancholic gaze reinvigorating the mood of lament and missed opportunities. Kevin asks, "What are you doing? Who are you doing?" upon which Chiron responds that he feels trapped, possibly by his performance of masculinity. The fact that they still seem to have feelings for each other makes Moonlight transcend issues of stabilizing or rationalizing narrative projects typically associated with queer representation (Halberstam, 2005).

Finally, Kevin asks if Chiron remembers the last time they saw each other whereby Chiron replies that he is trying to forget all those times. As such, memory seems to be a crucial point of difference between Call Me By Your Name and Moonlight. From an intersectionality perspective, the experience of being black seems to indicate even more stigma around homosexuality. In the final scene of the former, Oliver says that he remembers everything; in the latter, Chiron built himself up anew from the ground to make himself hard enough to repress the trauma of his past. Subsumed by normative political ideology, Chiron and Kevin ultimately seem to discuss how they can handle a subversive life torn between queer and repro time. In the final scene, Chiron admits that Kevin is the only person he has ever been intimate with. They caress each other gently before the enigmatic ending scene where we see a memory of Chiron as "Little" by the water.

\section{Portrait of a Lady on Fire}

The fifth full-length feature by French screenwriter-director Céline Sciamma (2019) is a historical drama with a near all-female cast, starring Noémie Merlant (Marianne) and Adéle Haenel (Héloïse) in the two leading roles. Set in France in the late 18th century, the film tells the story of a forbidden affair between Héloïse, a young aristocrat, and Marianne, a painter commissioned to paint her portrait. The film won the Queer Palm at Cannes, becoming the first film directed by a woman to win the award. Its cumulative worldwide gross is estimated to US $\$ 22.9 \mathrm{~m}$ against a budget of US\$4.3m (Box Office Mojo, 2020). The Guardian's film critic Mark Kermode (2020) notes how the film "seamlessly intertwines themes of love and politics, representation and reality" to create what Sciamma herself in multiple interviews has referred to as a manifesto for the female gaze. At every turn, the film subverts the male perspective in favor of feminine ways of looking.

A subplot about a young housemaid dealing with an unwanted pregnancy finds Sciamma depicting a taboo subject and its representation. With this in mind, it could be argued that Portrait of a Lady on Fire sees invisible intersections of identity that were silenced in Call Me By Your Name, as it takes issues of both class and sexuality into consideration. In her The New Yorker review, Syme (2020) points out that Sciamma based the subplot upon the book L'événement (2000) by Annie Ernaux. The book in question, in which she tells the story of an illegal abortion she had in 1963, at the age of 23, mourns the lack of great works of art that affirm or even depict her experience (Syme, 2020). "I do not believe there exists a 'Workshop of the Backstreet Abortionist' in any museum in the world," Ernaux (2000, p. 82) writes. This line

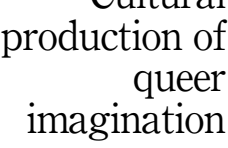

285 
AAM 11,3 struck a chord with the filmmaker Céline Sciamma who cited it as the inspiration for the striking scene in Portrait of a Lady on Fire (Syme, 2020).

Where many other directors of a period of lesbian romance might emphasize the taboos of same-sex love, Sciamma is less interested in shame or shock as she is in the force of the genuine bonds that form. In contrast to Moonlight and Call Me By Your Name, the two protagonists never have to question or come to terms with their burgeoning sexual awakening. They never explicitly address their sexual desire as if it were a problem. Sciamma's filming of sex and nudity sidesteps cinematic conventions. The only intercourse shown involves fingers in an armpit, and the only time we see Héloïse in the nude, she is stretched on a bed, a small mirror blocking her pubis hair as Marianne gazes at her own reflection sketching a self-portrait. The film's relative modesty feels like a rebuke to another acclaimed French lesbian romance Blue Is the Warmest Colour (2013), whose male director included a 6-min sex scene that the female stars later said they found demeaning (Aftab, 2013).

Toward the end of the movie, we are pulled back to the present. It is revealed that Marianne saw Héloïse on two more occasions. The first time was at a gallery in the form of a portrait, where Héloïse was shown with a child, surreptitiously holding a book open at Page 28 recalling the self-portrait Marianne drew in the mirror, which she requested on that page. The second time was at a concert where Héloïse was overwhelmed with emotions as the orchestra performed a piece from Vivaldi's Four Seasons, which Marianne had previously played for her on a harpsichord. While the narratological attitude toward remembrance is closer to that of Call Me By Your Name than Moonlight, the film ends on a note of subversion. Although Héloïse ultimately is subsumed by the inevitable constrictions of patriarchy, the wink when she held the book open at that significant page - as a gesture to indicate that her love and desire for Marianne never waned - suggests that she never truly committed to the repro time of heteronormativity. Rather, it was forced upon her by patriarchal structures. This has implications for Halberstam's (2005) framework for apparent motivations behind queer representation in cinema. It could be argued that Call Me By Your Name follows a rationalizing project, returning Oliver to the inevitability of hetero-domesticity; for Héloïse, however, this return exposes patriarchal structures and could, thus, be seen as a form of contemporary ideological critique on social identity. A similar inversion of Halberstam's (2005) framework is found in Moonlight when Chiron and Kevin (i.e. the temporarily stabilized vis-à-vis rationalized queer subjects) ultimately seem to reconcile and impose gender trouble in the film's enigmatic ending.

\section{Discussion}

With the aim of elucidating how cinematic representations of queer imagination (which following Marcuse is always already part of a commodifying process) possibly can transform market culture and ideologies around gender and sexuality, our analysis of the narrative attempts at "seeing the invisible" in three relatively recent additions to the genre of queer cinema provide some preliminary answers. Compared to Call Me By Your Name, we argue that Moonlight and Portrait of a Lady on Fire are more in line with Baldwin's prospect of queer imagination, in the sense that they see invisible, forbidden desires among marginal groups. While the former, according to Guadagnino, is not a gay movie but a film about "the beauty of the newborn idea of desire, unbiased and uncynical" (Wilson, 2017), there is a sense that Moonlight more explicitly seeks to give a voice to marginalized and subjugated groups that previously have been excluded from mainstream cinema and integrate those imaginaries into social praxis. The justification provided by Guadagnino is similar to that of Wong KarWai when addressing his feature film Happy Together (1997), a critically acclaimed chronicle of gay love (Lippe, 1998). Nonetheless, Kar-Wai states: 
In fact, I do not like people to see this film as a gay film. It's more like a story about human relationships and somehow the two characters involved are both men. Normally I hate movies with labels like "gay film," "art film" or "commercial film." There is only good film and bad film (Lippe, 1998, p. 58).

However, numerous intersections of identity remain excluded in both Moonlight and Call Me By Your Name. There are, for example, no interracial or lesbians relationships present. In those movies that actually do try to represent lesbian desire - such as Blue Is the Warmest Colour (2013) - the explicit scenes often seem to serve the purpose of pleasing the male gaze[2, 3]. It is also significant that Barry Jenkins's subsequent movie is an adaptation of Baldwin's If Beale Street Could Talk (1974) about racism and heterosexual love between two black teenagers in Harlem, rather than Giovanni's Room (1956) or the elegiac epic Just Above My Head (1979) that more explicitly deals with homosexual and interracial relationships.

While Portrait of a Lady on Fire, enriched by Sciamma's compelling subplot about an abortion, gives a seemingly authentic voice to lesbian desires and female anxieties, it has a significantly lower cumulative worldwide gross (US\$22.9m, Box Office Mojo, 2020) than both Call Me By Your Name (US\$41.9m, Box Office Mojo, 2018) and Moonlight (US\$65.3m, Box Office Mojo, 2017). However, by reinvigorating delicate social and political debates in the global mediascape, as indicated by the critical discourses they have spurred, we derive that all three films have compromising and transformative effects on commodity aesthetics, whereby queer imagination seems to serve as a counterpoint to normative political ideology (cf. Crockett and Wallendorf, 2004). It is also worth denoting that such activity is not limited to the screen. For example, in an offscreen protest against the film-industry patriarchy, Sciamma and Haenel recently walked out of the César Awards, France's version of the Oscars, when Roman Polanski, a convicted rapist, was announced as a winner (McHugh, 2020).

\section{Implications for arts marketing and cultural branding}

From the framework depicted in Figure 1, it follows that the social structure of queer imagination is inevitably subsumed by the heteronormative market forces seeking to gain a financial profit. More generally, this is evident when the agency seeking to partake in the cultural production of queer imagination neither is an insider nor perceived as credible by the insiders (Holt, 2004; also Tsai, 2010). Consider, for example, the recent film Falling (2020) in which the lead actor Viggo Mortensen - otherwise known as the sword-wielding hero Aragorn in the Lord of the Rings franchise - faced backlash for playing the role of a gay man. Adding to the complexity is the fact that the film is written and directed by Mortensen himself. In response to the controversy, he thinks people need to understand that we do not know everything there is to know about his life, so people should not judge what roles he takes.

Look, these are the times we're living in, and I think it's healthy that those issues are brought up. The short answer is that I did not think it was a problem. And people then ask me, 'Well what about Terry Chen, who plays my husband in the film, is he a homosexual?' And the answer is I do not know, and I would never have the temerity to ask someone if they were, during the casting process. And how do you know what my life is? You're assuming that I'm completely straight. Maybe I am, maybe I'm not. And it's frankly none of your business. I want my movie to work, and I want the character of John to be effective. So if I did not think it was a good idea I would not do it (Maher, 2020).

We derive that the theoretical formulation of false sublation provides a longitudinal perspective that is more amenable to describe how disruptive practices may have transformative effects on normative political ideology than similar courses of action such as cultural appropriation (Keene, 2015), in which elements of disadvantaged minority cultures are ignorantly adopted by members of a more dominant group (Kates, 2004), or
Cultural
production of
queer
imagination

287 
AAM 11,3

288

market co-optation, where subversive practices become shepherded into more predictable, manageable and regulated environments facilitated by normative market forces (Goulding et al., 2009; Heath and Potter, 2005; Thompson and Coskuner-Balli, 2007). Recently, the term "queerbaiting" has been used in cultural studies to criticize homoerotic suggestiveness in cultural production when this suggestiveness is never actualized (Brennan, 2018). As the name suggests, queerbaiting is the baiting of the queer community by subtly inferring characters might be gay, without ever explicitly saying it [4]. We derive from our analysis that the term could be stretched to describe the process by which Timothée Chalamet in Call Me By Your Name made use of the queer narrative as a springboard to launch his personal brand as "the hottest actor on the planet [...] redefining what it means to be a leading man" (Styles, 2019). Future research may wish to further explore the connection between queerbaiting and brand (in)authenticity.

To the best of our knowledge, Kates (2004) is the only scholar who has studied queer identity work in relation to the way consumers endow market experiences with authentic meaning. From a brand management perspective, authenticity helps overcome consumer skepticism toward brands and advertisements (Becker et al., 2019; Beverland and Farrelly, 2010). However, when brands chase after populist worlds incongruous to their cultural and/or political authority, they come off as "opportunistic cultural parasite[s]" (Holt, 2004, p. 198). Similarly, Kates (2004) provides texture to the market failure of Coors in North American queer communities. As the consumer segment knew that the beer brand was owned by a conservative family that donated money to anti-gay political causes, the brand's attempt to gain legitimacy failed despite aggressive marketing efforts.

In light of their precarious status as oppressed minorities, advertisers need to demonstrate sensitivity in targeting queer communities. From this perspective, authentic brands do not represent - they produce - queer imaginaries (by seeing the invisible). For example, rather than promoting nonconformist ideals, Holt (2004) demonstrates how Volkswagen's advertisements spoke from within the bohemian milieu to comment on what was going on:

[t]here were no smoky underground jazz clubs or poetry readings. Instead of trying to hop on the counterculture through imitation, Volkswagen acted like a particularly clever and creative insider (p. 70).

Years later, Volkswagen sought to authenticate its brand image by partaking in the cultural production of queer imagination when they aired the successful Sunday Afternoon commercial on the episode where American talk-show host Ellen DeGeneres came out as a lesbian (see Holt, 2004).

The queer theory can clearly help marketers develop authenticity for consumers by drawing on "rainbow rhetoric" (Kates, 1999, p. 35). However, it is not enough for marketers to become aware of this rhetoric to describe the diversity of queerness, spanning many intersections of social and political identity. They also need to understand the dynamics of false sublation by which queer imaginaries run the risk of affirming - rather than negating dominant ideologies. The success of Moonlight, Call Me By Your Name and Portrait of a Lady on Fire attest to the performative capability of popular culture to influence the authenticity formation process, where both queer and straight consumers appreciate queer imagination as a part of their consumption experiences.

As Beverland and Farrelly (2010) remind us, what remains consistent in the marketing literature is that "authenticity encapsulates what is genuine, real, and/or true" (p. 839). Nonetheless, despite issues of honoring brand heritage, Becker et al. (2019) identified divergent dimensions of authenticity in advertisements such as realism (i.e. whether the plot is realistic) and credibility (i.e. the advertisement presents a credible message). In a similar vein, Södergren (2019) demonstrates how Gillette recently sought to debunk its actual heritage - as manifested in the traditional slogan the best a man can get - by legitimizing the 
brand in a present-day ideological landscape through realistic and credible imagery depicting a transgender man's first shave, fueled by the warm gaze of his supportive father. Despite their efforts to convey an "authentic" representation of queer imagination (Figure 1), the advertisement could face backlash if it fails to reintegrate the imagery it conveys into brand praxis. Vredenburg et al. (2020) refer to this as woke-washing. However, such contributions to the commodification of queer life can still compromise normative political ideology by disseminating and normalizing queer imaginaries. This means that it is not necessarily the most realistic or credible representation of a queer imaginary that will be the most iconic or transformative. Other representations could have more transformative effects, as manifested in the longstanding obsession with metaphor and allegory in advertising text (Stern, 1988).

Brands are also recommended to "see the invisible" in indexical terms (Grayson and Martinec, 2004). Consider, for example, Tate Britain who have started to reclaim previously repressed queer histories and identities through key artwork in their canonical collection. In a recent video that is part of their TateShots series, three LGTBQ + advocates are invited to visit the museum to interpret and make sense of artworks on the basis of their own identities and experiences (Tate, 2019). Other brands could follow suit and highlight queer histories in their brand narratives.

Rather than "straightening up," the queer discourse by resolving tensions and paradoxes inherent in queer cinema and advertising scripts to endow the imagery with "straight" authenticity (Borgerson et al., 2006; cf. Rose and Wood, 2005), we suggest that the authenticity formation process is itself increasingly situated by queer imagination as a way to address desires, anxieties and alternative temporalities caused by acute cultural contradictions in society. Thus, false sublation is proposed as a novel framework to study the compromising effects of such representations on normative political ideology, regardless of the nominal or indexical authenticity. Herein lies the paradox that for an authentic representation of queer imagination to negate cultural hegemony, a false sublation might be necessary (Figure 1). Furthering Marcuse, it is indeed through this very affirmation that authentic brands may also have an emancipatory social function.

\section{Conclusion}

In this paper, we have described recent cultural disruptions contributing to the development of queer imagination and how brands possibly can tap into these narratives to project authenticity. Mainstream cinema partakes in the cultural production of queer imagination as an emergent market ideology that compromises the authenticity formation process, also affecting brand culture. Hence, we follow the range of scholars that study cultural aspects of aesthetics to understand consumer behavior (e.g. Brown, 2015b; Joy and Sherry 2003; Venkatesh and Meamber, 2006). Our main contribution has been to elucidate the dynamics between authenticity as a compromise vs false sublation in the context of queer cinema. Hence, we extend the literature on commodification and how cultural production contributes to the dissemination of ideological meaning in an aesthetically oriented consumer culture. In more practical terms, "seeing the invisible" is proposed as a cultural branding technique.

As testified by Coffin et al. (2019), "progress is rarely linear and uniform, and legal equality does not necessarily equal everyday socio-symbolic equality" (p. 284); hence, one should not assume that all categories pass through an even development. Such an evolutionist view would eradicate what is contradictory in historical processes, replacing it with the idea that development is a linear progress. Given the history of false sublation, one will need to ask whether a sublation of authentic cinema is desirable at all, whether the distance between aesthetic semblance and life praxis is not requisite for that performative and emancipatory space within which alternatives (e.g. queer imagination) to what exists (e.g. normative political ideology) become conceivable.

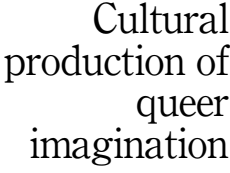

289 
One limitation of this study is that despite its aim to take intersectionality into consideration, the class perspective remains peripheral, which warrants future research where class is more clearly outlined in relation to sexual identity. An additional limitation of this study is the relatively small sample of films analyzed. A possible avenue for future research is, thus, to include a larger sample to enable validation of these findings. For example, ethnographic accounts from queer film festivals around the globe could possibly provide more depth to the culture industrial negotiation of authenticity. Finally, this study has focused on the representation of queer narratives in mainstream cinema. Further research may also include TV shows, which have gained considerable momentum in recent memory in the wake of online streaming services.

\section{Notes}

1. The Sámi people (also known as Lapps or Laplanders) are an indigenous Finno-Ugric people inhabiting large parts of northern Sweden, Finland and Norway.

2. This is in line with the rise of intimacy coordination and a more general understanding of screen sex scenes and misuse of power in the aftermath of \#MeToo (Pulver, 2021).

3. A notable exception is the Korean film The Handmaiden (2016) directed by Park Chan-wook but based on the book Fingersmith (2002) by Sarah Waters who is known for her novels set in Victorian society featuring lesbian protagonists.

4. Perhaps the most famous example of queerbaiting in popular culture was when J.K. Rowling made it publicly known that Dumbledore - one of the most beloved characters in her Harry Potter franchise is homosexual (without bothering to mention it in any of the seven books!). More recently, the Netflix hit Bridgerton has been accused of queerbaiting after prominently teasing gay sex scenes in its trailer but largely avoiding queer storytelling in the show itself (White, 2020).

\section{References}

Aftab, K. (2013), Blue Is the Warmest Colour Actresses on Their Lesbian Sex Scenes: 'We Felt like Prostitutes, The Independent, available at: https://www.independent.co.uk/arts-entertainment/ films/features/blue-is-the-warmest-colour-actresses-on-their-lesbian-sex-scenes-we-felt-likeprostitutes-8856909.html.

Arnould, E. and Price, L. (2000), "Authenticating acts and authoritative performances. Questing for self and community,", in Ratneshwar, S., Mick, D.G. and Huffman, C. (Eds), The Why of Consumption, Routledge, London, pp. 140-163.

Baldwin, J. (1956), Giovanni’s Room, Dial Press, New York, NY.

Baldwin, J. (1963), The Fire Next Time, The Dial Press, New York, NY.

Baldwin, J. (1964), Notes of a Native Son, Joseph, London.

Baldwin, J. (1970), Go Tell it on the Mountain, Dell, New York, NY.

Baldwin, J. (1974), If Beale Street Could Talk, Joseph, London.

Baldwin, J. (1979), Just above My Head, Joseph, London.

Becker, M., Wiegand, N. and Reinartz, W.J. (2019), "Does it pay to be real? Understanding authenticity in TV advertising", Journal of Marketing, Vol. 83 No. 1, pp. 24-50.

Benshoff, H. and Griffin, S. (Eds), (2004), Queer Cinema: The Film Reader, Routledge, New York, NY.

Beverland, M. (2005), "Crafting brand authenticity: the case of luxury wines", Journal of Management Studies, Vol. 42 No. 5, pp. 1003-1029.

Beverland, M. and Farrelly, F. (2010), "The quest for authenticity in consumption: consumers' purposive choice of authentic cues to shape experienced outcomes", Journal of Consumer Research, Vol. 36 No. 5, pp. 838-856. 
Beverland, M., Eckhardt, G., Sands, S. and Shankar, A. (2020), "How brands craft national identity", Journal of Consumer Research, Preprint, doi: 10.1093/jcr/ucaa062.

Borgerson, J.L., Schroeder, J.E., Blomberg, B. and Thorssén, E. (2006), "The gay family in the ad: consumer responses to non-traditional families in marketing communications", Journal of Marketing Management, Vol. 22 Nos 9-10, pp. 955-978.

Botterill, J. (2007), "Cowboys, outlaws and artists: the rhetoric of authenticity and contemporary jeans and sneaker advertisements", Journal of Consumer Culture, Vol. 7 No. 1, pp. 105-125.

Box Office Mojo (2017), "Box office mojo: moonlight", available at: https://www.boxofficemojo.com/ release/rl2558428673.

Box Office Mojo (2018), "Box Office Mojo: call me by your name”, available at: https://www. boxofficemojo.com/title/tt5726616.

Box Office Mojo (2020), "Box office mojo: portrait of a lady on fire", available at: https:/www. boxofficemojo.com/title/tt8613070.

Bradshaw, A. (2010), "Before method: axiomatic review of arts marketing", International Journal of Culture, Tourism and Hospitality Research, Vol. 4 No. 1, pp. 8-19.

Bradshaw, P. (2017), Call Me by Your Name Review - Gorgeous Gay Love Story Seduces and Overwhelms, The Guardian, available at: https:/www.theguardian.com/film/2017/oct/26/callme-by-your-name-review-luca-guadagnino-armie-hammer.

Brennan, J. (2018), “Queerbaiting: the 'playful' possibilities of homoeroticism”, International Journal of Cultural Studies, Vol. 21 No. 2, pp. 189-206.

Brim, M. (2014), James Baldwin and the Queer Imagination, The University of Michigan Press, Ann Arbor.

Bristor, J.M. and Fischer, E. (1993), "Feminist thought: implications for consumer research", Journal of Consumer Research, Vol. 19 No. 4, pp. 518-536.

Brown, S. (2015a), "Bow to Stern: can literary theory plumb an unfathomable brand?", Marketing Theory, Vol. 15 No. 4, pp. 445-464.

Brown, S. (2015b), "Brands on a wet, black bough: marketing the masterworks of modernism", Arts and the Market, Vol. 5 No. 1, pp. 5-24.

Brown, S. and Patterson, A. (2001), Imagining Marketing: Art, Aesthetics and the Avant-Garde, Routledge, New York, NY.

Brown, S., McDonagh, P. and Shultz, C.J. (2013), "Titanic: consuming the myths and meanings of an ambiguous brand", Journal of Consumer Research, Vol. 40 No. 4, pp. 595-614.

Bürger, P. (1984), Theory of the Avant-Garde, Manchester U.P., Manchester.

Butler, J. (2006), Gender Trouble: Feminism and the Subversion of Identity, Routledge, New York, NY.

Chan-Wook, P.(Director) (2016), The Handmaiden [Film], Moho Film, Yong Film, Seoul.

Coffin, J., Eichert, C. and Nölke, A. (2019), "Towards (and beyond) LGBTQ+ studies in marketing and consumer research", in Dobscha, S. (Ed.), Handbook of Research on Gender and Marketing, Edward Elgar Publishing, Cheltenham, pp. 273-293.

Columbus, C.(Director) (1993), Mrs. Doubtfire [Film], 20th Century Fox; Blue Wolf Productions, Los Angeles.

Crockett, D. and Wallendorf, M. (2004), "The role of normative political ideology in consumer behavior", Journal of Consumer Research, Vol. 31 No. 3, pp. 511-28.

De Palma, B.(Director) (1980), Dressed to Kill [Film], Cinema 77, Film Group, Sonoma County.

De Bernardi, C. (2019), "Authenticity as a compromise: a critical discourse analysis of Sámi tourism websites", Journal of Heritage Tourism, Vol. 14 No. 3, pp. 249-262.

De Lauretis, T. (1991), "Queer theory: lesbian and gay sexualities", in Lawrence, R. (Ed.), Differences: A Journal of Feminist Cultural Studies, Indiana University Press, Bloomington, IN.

production of
queer
imagination 
AAM 11,3

DeBerry-Spence, B. and Izberk-Bilgin, E. (2019), "Historicizing and authenticating African dress: diaspora double consciousness and narratives of heritage and community", Consumption Markets and Culture, Vol. 24 No. 2, pp. 147-168.

Derrida, J. (2016), Of Grammatology, Johns Hopkins University Press, Baltimore.

Ernaux, A. (2000), L'événement, Gallimard, Paris.

Fine, G.A. (2003), "Crafting authenticity: the validation of identity in self-taught art", Theory and Society, Vol. 32 No. 2, pp. 153-180.

Firat, A. and Venkatesh, A. (1995), "Liberatory postmodernism and the reenchantment of consumption”, Journal of Consumer Research, Vol. 22 No. 3, pp. 239-267.

Fisher, M. (2021), Postcapitalist Desire: The Final Lectures, Repeater, London.

Gardiner, B. (1973), Every Nigger Is a Star. On Every Nigger Is a Star, Jazzman, Hollywood.

Gerstner, D.A. (2019), "How do we look so far? Notes toward a queer-film philosophy", in Carroll, N., Di Summa, L. and Loht, S. (Eds), The Palgrave Handbook of the Philosophy of Film and Motion Pictures, Palgrave Macmillan, Basingstoke, pp. 699-720.

Gilmore, J. and Pine, B. (2007), Authenticity: What Consumers Really Want, Harvard Business Press, Boston.

Ginder, W. and Byun, S. (2015), "Past, present, and future of gay and lesbian consumer research: critical review of the quest for the queer dollar", Psychology and Marketing, Vol. 32 No. 8, pp. 821-841.

Gluckman, A. and Reed, B. (1997), Homo Economics - Capitalism, Community, and Lesbian and Gay Life, Routledge, London.

Goulding, C., Shankar, A., Elliott, R. and Canniford, R. (2009), “The marketplace management of illicit pleasure", Journal of Consumer Research, Vol. 35 No. 5, pp. 759-771.

Grayson, K. and Martinec, R. (2004), "Consumer perceptions of iconicity and indexicality and their influence on assessments of authentic market offerings", Journal of Consumer Research, Vol. 31 No. 2, pp. 296-312.

Grazian, D. (2005), Blue Chicago: The Search for Authenticity in Urban Blues Clubs, University of Chicago Press, Chicago.

Guadagnino, L.(Director) (2017), Call Me by Your Name [Film], Frenesy Film Company; La Cinéfacture; RT Features; M.Y.R.A. Entertainment; Water's End Productions, Rome.

Gurrieri, L. and Cherrier, H. (2013), "Queering beauty: fatshionistas in the fatosphere”, Qualitative Market Research: An International Journal, Vol. 16 No. 3, pp. 276-295.

Hafer, L. (2020), World of Warcraft's First Trans Character Is an Important Step Forward, PC Gamer, available at: https://www.pcgamer.com/world-of-warcrafts-first-trans-character-is-an-importantstep-forward/.

Halberstam, J. (2005), In a Queer Time and Place: Transgender Bodies, Subcultural Lives, New York University Press, New York, NY.

Hartmann, B. and Östberg, J. (2013), "Authenticating by re-enchantment: the discursive making of craft production”, Journal of Marketing Management, Vol. 29 Nos 7-8, pp. 882-911.

Hearn, J. and Hein, W. (2015), "Reframing gender and feminist knowledge construction in marketing and consumer research: missing feminisms and the case of men and masculinities", Journal of Marketing Management, Vol. 31 Nos 15-16, pp. 1626-1651.

Heath, J. and Potter, A. (2005), The Rebel Sell, HarperCollins, Toronto.

Hirschman, E. (1987), "Movies as myths: an interpretation of motion picture mythology", in Marketing and Semiotics: New Directions in the Study of Signs for Sale, pp. 335-74.

Hirschman, E. (1988), "The ideology of consumption: a structural-syntactical analysis of 'Dallas' and 'Dynasty", Journal of Consumer Research, Vol. 15 No. 3, pp. 344-359. 
Hitchcock, A.(Director) (1960), Psycho [Film], Shamley Productions, Hollywood.

Holbrook, M. (1995), "The four faces of commodification in the development of marketing knowledge", Journal of Marketing Management, Vol. 11 No. 7, pp. 641-654.

Holbrook, M. and Grayson, M. (1986), "The semiology of cinematic consumption: symbolic consumer behavior in out of Africa", Journal of Consumer Research, Vol. 13 No. 3, pp. 374-381.

Holt, D. (2004), How Brands Become Icons: The Principles of Cultural Branding, Harvard Business School Press, Boston, MA.

Holt, D. and Thompson, C. (2004), "Man-of-action heroes: the pursuit of heroic masculinity in everyday consumption", Journal of Consumer Research, Vol. 31 No. 2, pp. 425-440.

Horak, L. (2016), Girls Will Be Boys: Cross-Dressed Women, Lesbians, and American Cinema, 19081934, Rutgers University Press, New Jersey, NJ.

Hudson, L. and Ozanne, J. (1988), "Alternative ways of seeking knowledge in consumer research", Journal of Consumer Research, Vol. 14 No. 4, pp. 508-521.

Jenkins, B.(Director) (2016), Moonlight [Film], A24; Plan B Entertainment, Pastel Productions, New York.

Jones, A. (2009), "Queer heterotopias: homonormativity and the future of queerness", Interalia: A Journal of Queer Studies, Vol. 4, available at: http://www.interalia.org.pl/pl/artykuly/2009_4/ 13_queer_heterotopias_homonormativity_and_the_future_of_queerness.htm.

Joy, A. and Sherry, J.F. Jr (2003), "Speaking of art as embodied imagination: a multisensory approach to understanding aesthetic experience", Journal of Consumer Research, Vol. 30 No. 2, pp. 259-282.

Kar-Wai, W.(Director) (1997), Happy Together [Film], Block 2 Pictures; Jet Tone Production; Prenom H, Seawoo Film, New York.

Kates, S. (1999), "Making the ad perfectly queer: marketing 'normality' to the gay men's community?", Journal of Advertising, Vol. 28 No. 1, pp. 25-37.

Kates, S. (2000), "Out of the closet and out on the street!: gay men and their brand relationships", Psychology and Marketing, Vol. 17 No. 6, pp. 493-513.

Kates, S. (2004), "The dynamics of brand legitimacy: an interpretive study in the gay men's community", Journal of Consumer Research, Vol. 31 No. 2, pp. 455-464.

Keating, A. and McLoughlin, D. (2005), "Understanding the emergence of markets: a social constructionist perspective on gay economy”, Consumption, Markets and Culture, Vol. 8 No. 2, pp. 131-152.

Kechiche, A.(Director) (2013), Blue Is the Warmest Colour [Film], Wild Bunch; Quat'sous Films; France 2 Cinéma; Scope Pictures; Vértigo Films; Radio Télévision Belge Francofone; Eurimages; Pictanovo, Paris.

Keene, A. (2015), "Representations matter: serving Native students in higher education", Journal Committed to Social Change on Race and Ethnicity, Vol. 1, pp. 102-109.

Kermode, M. (2020), Portrait of a Lady on Fire Review - Mesmerised by the Female Gaze, The Guardian, available at: https://www.theguardian.com/film/2020/mar/01/portrait-of-a-lady-onfire-review-celine-sciamma.

Lasic, G. (2020), LGBTQ+ Fans Thanked Lady Gaga for Her Response to 'penis Rumors' in Resurfaced Interview, Inquirer, available at: https://pop.inquirer.net/91478/lgbtq-fans-commend-lady-gagapenis-rumor-hermaphrodite-interview.

Lippe, R. (1998), "Gay movies, west and east: in and out: Happy together”, CineAction, Vol. 45, pp. 52-59.

Maher, K. (2020), Viggo Mortensen: Lord of the Rings Hottie to Director of Arthouse Film Falling, The Times, available at: https://www.thetimes.co.uk/edition/times2/viggo-mortensen-interview-lordof-the-rings-hottie-to-director-of-arthouse-film-falling-d5mdd23bb.

\section{Cultural production of queer imagination}


Marcuse, H. (1968), Negations: Essays in Critical Theory, Beacon Press, Boston, MA.

Marcuse, H. (1969), "Repressive tolerance", in Wolff, R.P., Moore, B. and Marcuse, H. (Eds), A Critique of Pure Tolerance, Beacon Press, Boston, pp. 95-137.

Marcuse, H. (1972), Counter-Revolution and Revolt, Beacon Press, Boston.

Marcuse, H. (1977), The Aesthetic Dimension: A Critique of Marxist Aesthetics, Beacon Press, Boston.

McHugh, J. (2020), The Polanski Protests Have Brought France's \#MeToo Reckoning a Step Closer, The Guardian, available at: https:/www.theguardian.com/commentisfree/2020/mar/08/romanpolanski-metoo-france.

Mick, D.G. (1986), "Consumer research and semiotics: exploring the morphology of signs, symbols, and significance", Journal of Consumer Research, Vol. 13 No. 2, pp. 196-213.

Morhart, F., Malär, L., Guèvremont, A., Girardin, F. and Grohmann, B. (2015), "Brand authenticity: an integrative framework and measurement scale”, Journal of Consumer Psychology, Vol. 25 No. 2, pp. 200-218.

Mortensen, V.(Director) (2020), Falling [Film], Scythia Films, Toronto.

Muñoz, J.E. (2009), Cruising Utopia: The Then and There of Queer Futurity, New York University Press, New York, NY.

Napoli, J., Dickinson, S., Beverland, M. and Farrelly, F. (2014), "Measuring consumer-based brand authenticity", Journal of Business Research, Vol. 67 No. 6, pp. 1090-1098.

Peñaloza, L. (1996), "We're here, we're queer, and we're going shopping! A critical perspective on the accommodation of gays and lesbians in the US marketplace", Journal of Homosexuality, Vol. 31 Nos 1-2, pp. 9-41.

Peterson, R. (2005), "In search of authenticity", Journal of Management Studies, Vol. 42 No. 5, pp. 1083-1098.

Pollack, S.(Director) (1982), Tootsie [Film], Mirage Enterprises, Los Angeles.

Preece, C. (2014), "The branding of contemporary Chinese art and its politics", Arts Marketing: An International Journal, Vol. 4 Nos 1/2, pp. 25-44.

Pulver, A. (2021), 'It Was a Misuse of Power': How Screen Sex Scenes Have Been Forced to Change, The Guardian, available at: https://www.theguardian.com/film/2021/jan/29/it-was-a-misuse-ofpower-how-movie-sex-scenes-change-keira-knightley.

Rose, R. and Wood, S. (2005), "Paradox and the consumption of authenticity through reality television", Journal of Consumer Research, Vol. 32 No. 2, pp. 284-296.

Schallehn, M., Burmann, C. and Riley, N. (2014), "Brand authenticity: model development and empirical testing", Journal of Product and Brand Management, Vol. 23 No. 3, pp. 192-199.

Schroeder, J. (2005), “The artist and the brand”, European Journal of Marketing, Vol. 39 Nos 11/12, pp. 1291-1305.

Schroeder, J. and Zwick, D. (2004), "Mirrors of masculinity: representation and identity in advertising images", Consumption Markets and Culture, Vol. 7 No. 1, pp. 21-52.

Sciamma, C.(Director) (2019), Portrait of a Lady on Fire [Film], Lilles Films, Paris.

Seregina, A. (2019), "Undoing gender through performing the other", Consumption Markets and Culture, Vol. 22 No. 4, pp. 454-473.

Skinner, H. (2018), "Ethnic and cultural identity in music and song lyrics ethnic and cultural identity in music and song lyrics", Arts and the Market, Vol. 8 No. 1, pp. 113-114.

Södergren, J. (2019), "From aura to jargon: the social life of authentication", Arts and the Market, Vol. 9 No. 2, pp. 115-131.

Södergren, J. (2021), "Brand authenticity: 25 years of research", International Journal of Consumer Studies, Preprint, doi: 10.1111/ijcs.12651. 
Spiggle, S., Nguyen, H.T. and Caravella, M. (2012), "More than fit: brand extension authenticity", Journal of Marketing Research, Vol. 49 No. 6, pp. 967-983.

Stern, B. (1988), "How does an ad mean? Language in advertising", Journal of Advertising, Vol. 17 Summer, pp. 3-14.

Stern, B. (1994), "Authenticity and the textual persona: postmodern paradoxes in advertising narrative", International Journal of Research in Marketing, Vol. 11 No. 4, pp. 387-400.

Styles, H. (2019), “A decade of I-D covers: timothée chalamet meets harry styles, 2018”, I-D Magazine, available at: https://i-d.vice.com/en_uk/article/y3mzwj/24-must-watch-films-from-a24.

Syme, R. (2020), "Portrait of a lady on fire is more than a manifesto on the female gaze", New York Times, available at: https://www.newyorker.com/culture/cultural-comment/portrait-of-a-ladyon-fire-is-more-than-a-manifesto-on-the-female-gaze.

Tate (2019), "LGBTQ+ icons at tate Britain - sasha velour, munroe bergdorf and leo kalyan: tate shots [video]", YouTube, available at: https://youtu.be/frlmj-e9pyM.

Thompson, C. and Coskuner-Balli, G. (2007), "Countervailing market responses to corporate cooptation and the ideological recruitment of consumption communities", Journal of Consumer Research, Vol. 34 No. 2, pp. 135-152.

Thompson, C. and Üstüner, T. (2015), "Women skating on the edge: marketplace performances as ideological edgework", Journal of Consumer Research, Vol. 42 No. 2, pp. 235-265.

Thompson, C., Rindfleisch, A. and Arsel, Z. (2006), "Emotional branding and the strategic value of the doppelgänger brand image", Journal of Marketing, Vol. 70 No. 1, pp. 50-64.

Thompson, C., Arnould, E. and Giesler, M. (2013), "Discursivity, difference, and disruption: genealogical reflections on the consumer culture theory heteroglossia", Marketing Theory, Vol. 13 No. 2, pp. 149-174.

Tsai, W.H.S. (2010), "Assimilating the queers: representations of lesbians, gay men, bisexual, and transgender people in mainstream advertising", Advertising and Society Review, Vol. 11 No. 1, doi: 10.1353 asr.0.0042.

Venkatesh, A. and Meamber, L.A. (2006), "Arts and aesthetics: marketing and cultural production”, Marketing Theory, Vol. 6 No. 1, pp. 11-39.

von Sternberg, J.(Director) (1930), Morocco [Film], Paramount Pictures, Los Angeles.

Vredenburg, J., Kapitan, S., Spry, A. and Kemper, J.A. (2020), "Brands taking a stand: authentic brand activism or woke washing?", Journal of Public Policy and Marketing, Vol. 39 No. 4, pp. 444-460.

Vygotsky, L.S. (2004), "Imagination and creativity in childhood", Journal of Russian and East European Psychology, Vol. 42 No. 1, pp. 7-97.

Wang, N. (1999), "Rethinking authenticity in tourism experience", Annals of Tourism Research, Vol. 26 No. 2, pp. 349-370.

Waters, S. (2002), Fingersmith, Virago, London.

White, A. (2020), "Bridgerton: Netflix hit accused of 'queerbaiting' over lack of gay storylines", The Independent, available at: https://www.independent.co.uk/arts-entertainment/tv/news/ bridgerton-gay-benedict-netflix-b1780244.html.

Wilson, N. (2011), "The business of authenticity: a false relation?", Arts Marketing, Vol. 1 No. 2, pp. $159-170$.

Wilson, M. (2017), "Have coming-of-age movies come of age?", Henley Standard, available at: https:// www.henleystandard.co.uk/news/cinema/117847/have-coming-of-age-movies-come-of-age.html? refresh_ce.

\section{Cultural production of queer imagination}

295 


$\begin{array}{ll}\text { AAM } & \text { Appendix } \\ 11,3 & \end{array}$

\begin{tabular}{|c|c|c|}
\hline Title & Cinematic release & Director(s) \\
\hline A Fantastic Woman & 2017 & Sebastián Lelio \\
\hline A Single Man & 2009 & Tom Ford \\
\hline A Thousand Clouds of Peace & 2003 & Julián Hernández \\
\hline A Year Without Love & 2005 & Anahí Berneri \\
\hline Absent & 2011 & Marco Berger \\
\hline All Over Me & 1997 & Alex Sichel \\
\hline Beauty & 2011 & Oliver Hermanus \\
\hline Blue Is the Warmest Colour & 2013 & Abdellatif Kechiche \\
\hline BPM (Beats per Minute) & 2017 & Robin Campillo \\
\hline Brief Story from the Green Planet & 2019 & Santiago Loza \\
\hline Brokeback Mountain & 2005 & Ang Lee \\
\hline Call Me By Your Name & 2017 & Luca Guadagnino \\
\hline Carol & 2015 & Todd Haynes \\
\hline Coming Out & 1989 & Heiner Carow \\
\hline Ema & 2019 & Pablo Larraín \\
\hline Girl & 2018 & Lukas Dhont \\
\hline Girlhood & 2014 & Céline Sciamma \\
\hline Go Fish & 1994 & Rose Troche \\
\hline Hard Paint & 2018 & Filipe Matzembacher and Marcio Reolon \\
\hline Happy Together & 1997 & Wong Kar-wai \\
\hline Heartstone & 2016 & Guðmundur Arnar Guðmundsson \\
\hline Hedwig and the Angry Inch & 2001 & John Cameron Mitchell \\
\hline Hold You Tight & 1998 & Stanley Kwan \\
\hline How to Talk to Girls at Parties & 2017 & John Cameron Mitchell \\
\hline In the Future & 2010 & Mauro Andrizzi \\
\hline In the Name Of & 2013 & Małgorzata Szumowska \\
\hline José & 2018 & Cheng Li \\
\hline Kaboom & 2010 & Gregg Araki \\
\hline Keep the Lights On & 2012 & Ira Sachs \\
\hline Laurence Anyways & 2012 & Xavier Dolan \\
\hline Looking for Langston & 1989 & Isaac Julien \\
\hline Mommy & 2014 & Xavier Dolan \\
\hline Moonlight & 2016 & Barry Jenkins \\
\hline Nasty Baby & 2015 & Sebastián Silva \\
\hline No Hard Feelings & 2020 & Faraz Shariat \\
\hline One Day in a Life & 2008 & Stefano Tummolini \\
\hline Pain and Glory & 2019 & Pedro Almodóvar \\
\hline Philomena & 2013 & Stephen Frears \\
\hline Poison & 1991 & Todd Haynes \\
\hline Portrait of a Lady on Fire & 2019 & Céline Sciamma \\
\hline Pride & 2014 & Matthew Warchus \\
\hline Raging Sun, Raging Sky & 2009 & Julián Hernández \\
\hline Reinventing Marvin & 2017 & Anne Fontaine \\
\hline Show Me Love & 1998 & Lukas Moodysson \\
\hline Spider Lilies & 2007 & Zero Chou \\
\hline Stranger by the Lake & 2013 & Alain Guiraudie \\
\hline Summer Nights & 2014 & Mario Fanfani \\
\hline
\end{tabular}

Table A1. 


\begin{tabular}{|c|c|c|c|}
\hline Title & Cinematic release & Director(s) & $\begin{array}{l}\text { Cultural } \\
\text { production }\end{array}$ \\
\hline The Amazing Truth About Queen Raquela & 2008 & Olaf de Fleur Johannesson & queer \\
\hline The Blossoming of Maximo Oliveros & 2005 & Auraeus Solito & ima \\
\hline The Danish Girl & 2015 & Tom Hooper & imagination \\
\hline The Handmaiden & 2016 & Park Chan-wook & \\
\hline The Kids Are All Right & 2010 & Lisa Cholodenko & \\
\hline The Last of England & 1987 & Derek Jarman & 297 \\
\hline The Last Supper & 1995 & Cynthia Roberts & \\
\hline The Law of Desire & 1987 & Pedro Almodóvar & \\
\hline The Lives of Thérèse & 2016 & Sébastien Lifshitz & \\
\hline The Lobster & 2015 & Yorgos Lanthimos & \\
\hline The Prince & 2019 & Sebastián Muñoz & \\
\hline The Shape of Water & 2017 & Guillermo del Toro & \\
\hline The Speed of Life & 2007 & Edward Radtke & \\
\hline The Watermelon Woman & 1996 & Cheryl Dunye & \\
\hline The Way He Looks & 2014 & Daniel Ribeiro & \\
\hline The Wedding Banquet & 1993 & Ang Lee & \\
\hline The Weight & 2012 & Jeon Kyu-hwan & \\
\hline Together Alone & 1991 & P.J. Castellenata & \\
\hline Tomcat & 2016 & Händl Klaus & \\
\hline Walking on Water & 2002 & Tony Ayres & \\
\hline Water Drops on Burning Rocks & 2000 & François Ozon & \\
\hline Wild Side & 2004 & Sébastien Lifshitz & \\
\hline Wilde Salomé & 2011 & Al Pacino & \\
\hline Wittgenstein & 1993 & Derek Jarman & Table A1. \\
\hline
\end{tabular}

\section{Corresponding author}

Jonatan Södergren can be contacted at: jonatan.sodergren@sbs.su.se

For instructions on how to order reprints of this article, please visit our website:

www.emeraldgrouppublishing.com/licensing/reprints.htm

Or contact us for further details: permissions@emeraldinsight.com 